\title{
Research Areas in Post-Mining - Experiences from German Hard Coal Mining
}

\author{
Jürgen KRETSCHMANN ${ }^{1, *)}$, Nga NGUYEN ${ }^{2)}$
}

\author{
1) TH Georg Agricola University, Bochum, Germany; email: juergen.kretschmann@thga.de \\ ${ }^{2)}$ Hanoi University of Mining and Geology, Hanoi, Vietnam; email: nguyenthihoainga@humg.edu.vn
}

http://doi.org/10.29227/IM-2020-02-31

Submission date: 06-03-2020 | Review date: 22-09-2020

\section{Abstract}

The German hard coal mining industry closed its last active mine at the end of the year 2018. The Research Institute for Post-Mining (FZN) at TH Georg Agricola University (THGA) in Bochum/Germany, has developed an integrated approach to meet the challenges of the post-mining era. Therefore, post-mining covers four research areas: Perpetual tasks and mine water management; Geomonitoring in post-mining; Material science for the preservation of industrial heritage; Reactivation and transition.

The institute is trying to fulfill central requirements of the UN to deal responsibly and sustainably with the resources of our planet. It plans to be a part of a national and international network in the interest of all social groups and the environment.

Keywords: post-mining, industrial heritage, sustainably, coal mining industry

\section{Introduction}

The term "post-mining" refers to all processes and tasks involved once the natural resource has been extracted. Besides the direct activities incurred in securing and redeveloping mining legacies, this also entails the long-term geomonitoring and sustainable management of repositories as well as the areas used.

Classic issues include the risk management of old mining activities as well as the renaturation and recultivation of areas previously used for mining. Alongside groundwater and pit water management of coal and lignite mining industries, activities concern the abandonment of oil and gas industrial sites (1). This also encompasses the geomonitoring of post-mining processes and interactions, e.g. mining-induced ground motion. The basis of this work is access to extensive data, information, and superior knowledge management.

As part of its activities, the TH Georg Agricola University (THGA), Bochum/Germany, has established a Research Institute for Post-Mining (FZN) where new methods of geotechnical engineering will be developed and tested for sustainable management of mining impacts. The researchers working there explore the urgent issues that are arising as the miners leave: How can regions cope with the rise of mine water levels? What happens with the mine gas? How can abandoned mines be "cleaned up" and put to new intelligent use? Moreover, how can the impact of mining be monitored? These issues will keep researchers busy, partly on a permanent basis. Therefore, post-mining covers four research areas: Perpetual tasks and mine water management; Geomonitoring in post-mining; Material science for the preservation of industrial heritage; Reactivation and transition (Figure 1).

\section{Perpetual tasks and Mine Water Management}

With particular regard to post-mining, the mining authorities - in close collaboration with the mining companies have developed risk management that enables to identify and monitor all risks and define suitable measures. The risk fields of abandoned mine sites can be divided into the following categories (Figure 2):

- close to surface extractions;

- $\quad$ surface openings, shafts;

- $\quad$ subsidence, uplifts;

- discontinuous faults;

- mine gas emission at the ground surface;

- $\quad$ surface water management;

- mine water drainage;

- reuse of dump hills;

- rehabilitation of former operation areas (real property).

Mining water drainage is probably the biggest challenge in Germany. Mining water is rainwater that infiltrates into the ground along with permeable rock layers and fractures. The rainwater dissolves minerals in the rock, e. g. salts (2). In underground hard coal mining, the mine water must be pumped to the surface as otherwise it could rise and merge with drinking water (2).

In general, the extraction of raw materials in the underground can have manifold effects on the regional water balance. The end of the active extraction of raw materials usually leads to a rise of the water to its original water level. Associated with this are hydrogeological, hydrochemical, geochemical and geomechanical processes. The research activities focus on modelling and monitoring these complex processes and their interdependencies resulting in an environmental impact prediction, thus developing a broader understanding of systems and processes. The developments and their application thus make an important contribution to the compliance with the EU Water Framework Directive.

The energetic valorization of mine water is another important topic. Every year, approximately $70 \mathrm{M} \mathrm{m} 3$ of mine water is pumped in the Ruhr area. The temperature of this mine water is 35 to $40^{\circ} \mathrm{C}$. Applications of warm mine water are currently focused on local, geothermal heat utilization in individual projects and buildings. However, there are tech- 


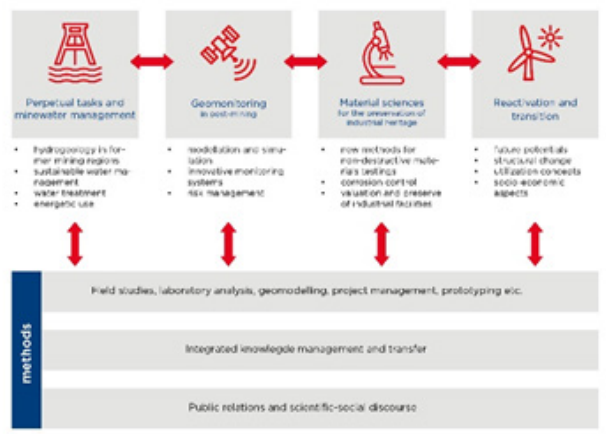

Fig. 1. Research areas of the Research Institute for Post-Mining at the THGA

Rys. 1. Obszary badawacze Instytutu Terenów Pogórniczych w THGA

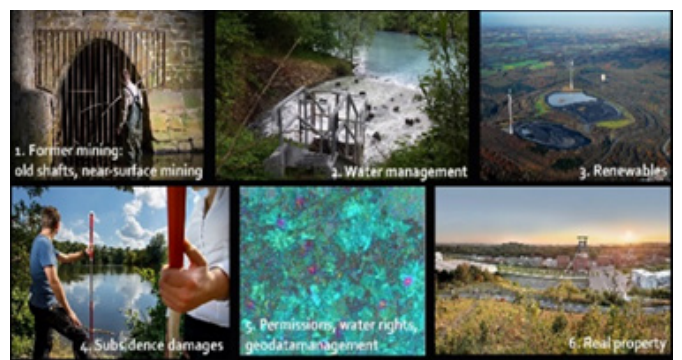

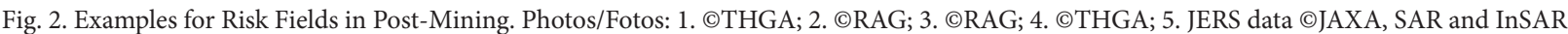
processing by Gamma Remote Sensing AG, 1998; @Brüggemann

Rys. 2. Przykłady pól ryzyka w zagadnieniach związanych z terenami pogórniczymi. Zdjęcia: 1. (THGA; 2. CRAG; 3. CRAG; 4. @THGA; 5. JERS data @JAXA, SAR and InSAR processing by Gamma Remote Sensing AG, 1998; @Brüggemann

nical possibilities for low-temperature electricity generation from warm mine water. Scientists are developing such technologies for this request.

Furthermore, separation techniques for the treatment of water from mining and industrial brownfields are being developed and tested in micro plants. The FZN at the THGA is dedicated to develop integrated approaches.

\section{Geomonitoring in post-mining}

Worldwide, former mining activities affect many regions; some of them taking place centuries ago. In many cases, the extraction and processing of raw materials are not documented and thus carries an inherent risk to humans and the environment. In this research area, the researchers develop technical systems for the monitoring of post-mining activities with the aim of combining remote-sensing methods, sensors and robotics, modelling and/or simulating the risks and bringing them together to form integrated risk management systems. Thus, in the future, all essential processes in post-mining can be monitored efficiently, and preventive measures can be initiated.

The application of satellite data i. e. from the EU-Copernicus program allows the detection of ground motion and thus the potential prognosis of the occurrence of subsidence and sinkholes. This program aims to supply high-resolution data of remote sensing for both space and time. By integrating the results from remote sensing with the underground analyses, in particular, the overburden, significantly improved interpretations and forecasts can be achieved, which are also important for risk management.

A typical specific challenge of mining processes is the large impact of land consumption and that they are operated over long periods of time. Contrary to that, there are certain processes that happen on a small scale and in a short period. One example of such local impacts is the discontinuity zones at tectonic faults or subsidence of shaft abandonments. Consequently, we need to search for methods and combinations that are robust and reliable regarding the process to be monitored.

The Copernicus Program launched by the European Union and the European Space Agency (ESA) provides an upto-date and high-performing infrastructure for earth observation and geo-information services. The program has seen the development of the Copernicus Sentinels - seven satellite missions that were specially developed for this program and that monitor space. They are at the heart of the space component (Figure 3).

The Sentinel satellites move in polar orbits at the height of approximately 700 to $800 \mathrm{~km}$. Their observations cover nearly every point of the Earth's surface. One major topic in this context is, of course, "Big Data". Indeed, the Sentinel satellites generate gigantic amounts of data that must be processed, provided to users and, in particular, stored for a long period of time. Together with partners, the FZN works on the use of satellite data for remote sensing and for monitoring actual processes of post-mining. The focus lies on the following aspects: the groundwater level, the land use, the land coverage, and the ground motion. Regarding the potential that is offered by the Copernicus Program and the reliability of the data supply, monitoring can be innovated by linking the information generated by the satellite-supported sensors with terrestrial expertise, something that we call the in-situ component. This process can help to mitigate the risks of post-mining and to strengthen its opportunities, e. g., providing new use and 


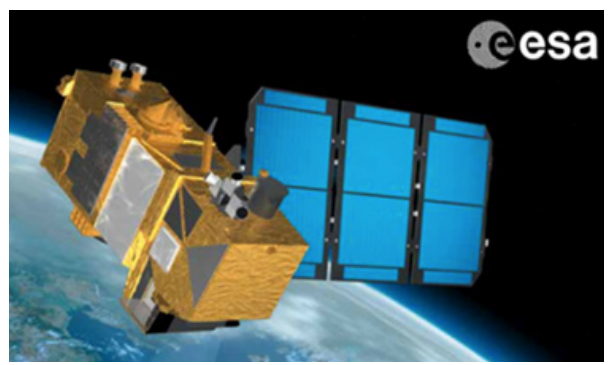

Fig. 3. Sentinel 2A. Photo/Foto: ESA

Rys. 3. Sentinel 2A. Zdjęcie: ESA

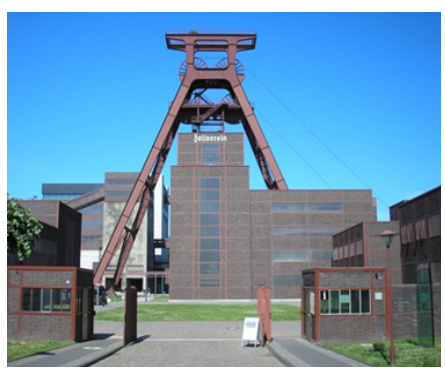

Fig. 4. Industrial monument: pit frame head of shaft XII of colliery Zollverein. Photo/Foto: Stiftung Zollverein/Jochen Track Rys. 4. Zabytek techniki: wieża szybu XII kopalni Zollverein. Zdjęcie: Stiftung Zollverein/Jochen Track

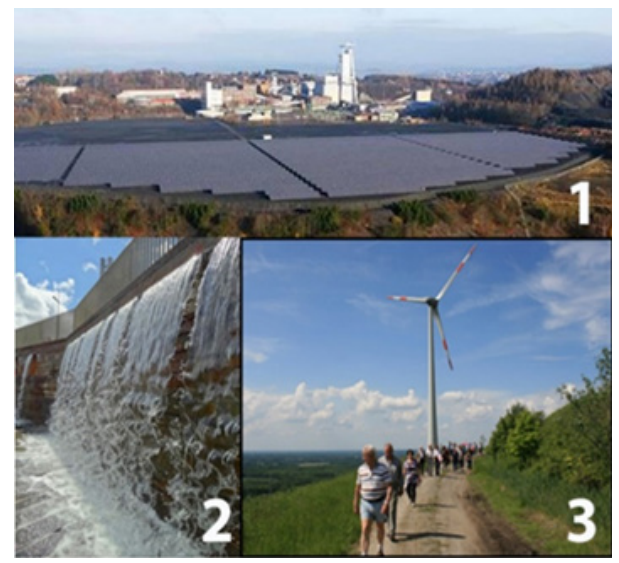

Fig. 5. Creating renewable energy, an opportunity of post-mining. 1) Photovoltaic plant on a mud pond; 2) Heat from mine water; 3) Windmill on a dump hill. (14)

Rys. 5. Wytwarzanie energii odnawialnej, szansa dla terenów pogórniczych. 1) Elektrownia fotowoltaiczna na terenie stawu osadowego; 2) energia ciepła z wód kopalnianych; 3) Wiatrak na zwałowisku odpadów. (14)

value to the old mining infrastructure to generate renewable energies.

Mining activities do cause ground motion. The use of satellite-supported remote sensing methods allows implementing monitoring of such ground motion without local installations being necessary.

The study site Kirchheller Heide, a heath located in the northern part of the Ruhr area, was used to develop change detection methods for water bodies and soil moisture due to mining-related ground motion. Mine-related flooding can be evaluated either directly by monitoring changes in water distribution or indirectly by observing changes in vegetation provoked by changes in soil moisture and water emergence (3). Plants around mine-related flooded areas often simply die, and rings of trees in different stages of decay can be observed.

Radar interferometry is an appropriate option for monitoring large-scale surfaces. As recent evaluations have shown a very high accuracy can be assumed for subsidence/settlement monitoring of buildings and landscape formations where contributing missions like TerraSAR-X data are used. In rural regions, artificial radar reflectors, e. g. corner reflectors can be erected.

Ground motion monitoring of larger areas, e. g. the entire Ruhr area, at high temporal frequencies, is an option, not only because of the higher intake capacity of the Copernicus radar mission Sentinel 1, which will enable a repeat rate of five to ten days for interferometric radar measurements relying on two satellites of identical construction.

Besides the Copernicus Program, in situ monitoring includes observation systems that are not operated in space. Such systems are, e. g.:

- $\quad$ surveying results of geodesy and mine-surveying;

- $\quad$ air-based remote sensing instruments;

- $\quad$ site inspection; 


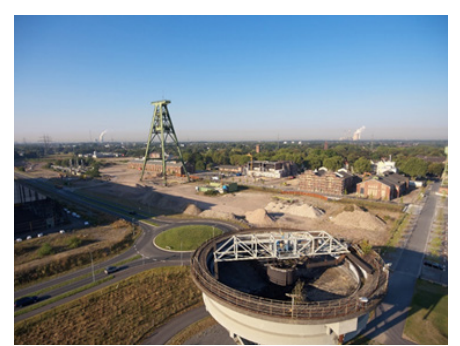

Fig. 6. Kreativ.Quartier Lohberg. Overview. Photo/Foto: RAG/Klingenburg

Rys. 6. Kreativ.Quartier Lohberg. Przegląd. Zdjęcie: RAG/Klingenburg

- $\quad$ photography and photogrammetry;

- meteorological measuring facilities;

- $\quad$ surface-based measuring facilities (4);

- probes at weather balloons;

- measuring buoys, stream gauging devices.

Likewise, information products that derive from such observations are part of the in-situ component. Those include e. g.:

- digital topographic maps;

- digital elevation models;

- ortho-photos;

- road networks;

- topical maps, e. g. forest areas, settlements, water bodies;

- mining charts.

The application and deployment of the several methods of the in-situ component are depended on the requirements defined by the post-mining specialists. The objective of the integration of the different methods lies in the open transparency of the available data and acceptance of the monitoring results (5).

\section{Material science for the preservation of Industrial Heritage}

Industrial development had formative regional importance on society and architecture in Germany, especially in the Ruhr region in the state of North-Rhine Westphalia but also in other regions of Germany. Driven by the availability of hard coal, an agglomeration of industrial influenced cities arose since the early 19th century. Today these cities are forming a metropolitan area with more than five million inhabitants. In this setting, numerous objects of coal mining concerning extraction, production, transport, and infrastructure have been built and are architectural highlights/architectural landmarks of the "coal age" in Germany. One example is the colliery and coking plant Zollverein in Essen, which is a World Heritage site on the UNESCO list (Figure 4).

Mining has left behind a numerous amount of surface installations, such as headframes, buildings, machine halls, coking plants, and blast furnaces, but also individual machines and equipment. In many cases, these objects form part of the industrial heritage and culture. Communities and people are eager to preserve this heritage for future generations but also for the utilization of the mining and industrial sites. The preservation of these objects requires a material-oriented solution and tailor-made material handling.

Materials science can offer solutions for the preservation of industrial culture. However, they must be further developed - case-related as well as related to object groups. As dif- ferent as these objects and materials are - they have one thing in common - they are old. Only when the ageing processes of the materials have been researched and understood can the decay be slowed down or, at best, the object can be preserved. Methods for estimating the durability of materials under specific stress conditions are developed. In addition, researchers examine the corrosion processes, test preservatives on damaged material and analyze the extent to which the material can be stabilized, and the process of deterioration reduced.

The idea of preservation of decommissioned industrial sites to keep the regional identity started simultaneously to the decline of the heavy industry in the Ruhr region. First, some workers' settlements were kept. Later a group of interested citizens, together with monument curators and politicians, recognized the historical significance of entire industrial sites, including pit frame heads or production halls with dimensions to speak of "industrial cathedrals" (6).

A positive result in the preservation and development of a mine site for new purposes can only be achieved in a consensus between the stakeholders concerned. Thus, very puristic preservation of a mine site - just keeping most of the object in an original condition - may be a success for the preservation authorities but may also cause the disinterest of owners and investors regarding the future use of the object. A resulting lack of funding is of a great disadvantage because it would prevent necessary maintenance and repair. The survival of a mine site without a new compatible use is possible only under very rare circumstances. However, a reuse of the site just with the consideration of user interests might result in a reconstruction that has nothing to do with the former monument. In this case, the uniqueness, the image, and the charisma of the object would be gone.

The regional tourist project entitled "Route der Industriekultur" (“The Industrial Heritage Trail”), a ca. $400 \mathrm{~km}$ circular route around the Ruhr area, is a core project to explain the region's industrial heritage to visitors. Twenty-six so-called anchor points make up the network of the trail, including six museums of technical and social history, many panorama points and a series of significant workers' settlements. The trail opens access to important witnesses of 750 years of industrial history in the region, and to the process of structural transformation that has been taking place here for several decades. The factory sites - many of which are under a preservation order - are not sites of nostalgia and regret. They have long been transformed into lively industrial venues and attractive centres for cultural and tourist events (7).

Actual attempts and successes at the Ruhr demonstrate that formerly ugly mine sites have been transferred into ap- 
preciated and accepted objects of mining culture. An important factor of success is the explanation of measures to the public. People were invited to join the long way of conversion from the state of industrially functional buildings (with sweat and tears) to the identity-forming objects of mining culture (with joy and pleasure). The aim of the people in charge was to explain the social significance of these objects to the public. Potential problematic objects were turned into places with a positive image because measures that are just enacted by certain experts and not discussed in public will fail to be accepted as socially valuable (6).

The attempts in the last 40 years have created a new atmosphere in the entire region. The declaration of the town of Essen together with the Ruhr region as the Cultural Capital of Europe in 2010 was an important milestone on this way to a bright post-mining future. The enthusiasm of the inhabitants and the increase of foreign tourists, indicated by an increasing number of visitors every year, illustrate that industrial, especially mining culture has become an important brand of this region. 10.5 million visitors attended the Capital of Culture events (8).

In 2017, the former mining town of Essen won the European Green Capital Award by Europe. The European commissioner responsible, Karmenu Vella, pointed out Essen had used the lessons from its industrial past to build an environmentally sound future (9).

\section{Reactivation and Transformation}

Shutting down mines has an impact on the socio-economic development of their surroundings. New jobs must be created, the old sites have to be re-utilized, and a just transition is of utmost importance for the region. The Ruhr area achieved this transition process within the last three decades and can form a lighthouse project for other regions in the world.

In this research area, the effects of reactivation and transition under socio-economic aspects are examined and evaluated. Regional and international economic surveys and assessments of contaminated sites of various decommissioned mining sectors are carried out. Using case studies on the relationships between decommissioning, post-mining and structural change, particularly in former coal mining areas with a focus on the Ruhr district, the drivers and processes of structural change as well as the success factors of structur$\mathrm{al}$ and regional planning measures for the regions concerned are examined. Scientists develop local and regional economic monitoring, apply and conduct comparative studies to similar transformation processes of other branches of industry. Researchers analyze the market and innovation potential arising in post-mining areas by, among other things, conducting socio-economic SWOT analyses. Particularly, these investigations help companies to further develop and market their products and knowledge in post-mining and reactivation.

Sustainable transformation means actively developing a mining region towards a sustainable future. Following management principles - defining goals, creating strategies and plans, undertaking measures (10) - it can be defined as "the sum or composition of all related/possible/suitable philosophies, visions, ideas, goals, concepts, programs, plans, measures and actions in order to achieve sustainable development in urban and rural areas" (11).
Sustainable transformation can be perceived as a "knowledge-based procedure" (12) It should aim towards long-term enhancements in the economic, ecological, and social capabilities of land and comprise the long-term consequences risks and opportunities of planning and acting today. Technologies and methods to survey, monitor, plan and develop a region are available, should be used efficiently and must be continuously improved. Regional management goes far beyond typical sectors, such as mining, agriculture and forestry, and includes aspects of water use, preservation of the soil, biodiversity, regional pricing, relationship of rural and city settlements, quality of life, division into degrading and prospering regions, etc.

By adopting procedures of quality management, an incremental but steady improvement of current use can be reached, and negative consequences of earlier or current misuse can be mitigated or remediated before they escalate. Continuous improvements contributing to a transformation strategy in a realistic, evolutionary way are much better than following big master plans orientated on utopic images of the far future. Former German Federal Minister for the Environment and Head of the UN Environment Program Klaus Töpfer describes the advantages of a down-to-earth strategy to be a visionary one: "Holistic approaches are destined to fail. I'm much more interested in having a clear direction and then going that way. Take small steps, make incremental changes, and you'll see the world is changing much faster than you expected. All those asking for the "Big Bang" change, they've been asking for years, and they forget to act." (13).

Why is a sustainable transformation important for mining regions? Because the decision to disinvest and close a mine might only take one single meeting. Nevertheless, to compensate for the effects of such a decision in the mining region might cost a generation in time. It is a question of risk management to minimize the external effects of disinvestment in a region and to use the potentials from it.

Creating new jobs is an on-going challenge in a declining mining region. In the last years, the energy industry in Germany has undergone a fundamental change towards renewable energies. This change brought surprising opportunities to generate renewable energies in the post-mining regions to create new jobs besides creating other new, future-orientated uses for former operating areas. In the Ruhr area, several applications have been developed and are already in use or exist as research projects, prototypes, ideas, and visions such as:

- Photovoltaic plants on mining dumps: Apart from their height, dump hills have another advantage: There are many free areas and hardly any shading. Therefore, they are ideal locations for photovoltaic systems; likewise, the large roofs of factory buildings can be used for these, too (Figure 5.1).

- Heat from mine water for supplying heating to buildings or for accelerating the biomass production when generating energy (Figure 5.2).

- Wind turbines on dump hills: The dump hills in the Ruhr area are often 80 to $100 \mathrm{~m}$ above the ground surface. Thus, they often feature high wind speeds that allow for economically reasonable use of wind turbines (Figure 5.3).

- Energy production from methane that is released from coal beds. 
- Production of biomass on former mining areas especially dumps hills.

- $\quad$ Pump-storage power plants using dump hills and underground mine structure.

- $\quad$ Production of geothermal energy (14).

An example where all three aims of sustainability - social, economic, and ecological - have been reached by reshaping a mine site is the Kreativ. Quartier Lohberg in the western Ruhr district (Figure 6). This development project illustrates the transformation of a former mine site into the first $\mathrm{CO} 2$ neutral suburb of Germany. An important feature of this site is the combination of modern and listed architecture that is completely supplied by renewable energy resources such as photovoltaic plants, heat from mine water, biomass, wind turbines and geothermal energy (15).

\section{Post-Mining Education - The Basis for Post-Mining Ex- cellence}

Post-mining excellence requires high motivation as well as a high level of abilities and skills. Without key elements such as ideas and visions, research and development, integration of surface and underground challenges, and risk management, post-mining will be inefficient, based on short-term thinking, muddling through or, in the worst case, on lip services. High motivation needs a change of mind. Post-mining no longer means simply avoiding certain hazards but must be a sustainable evolutionary process that is based on the management of risks and the utilization of opportunities. This process should be encouraged by suitable governmental regulations and incentives to promote ideas, to support research and development, and to run widely visible lighthouse projects profitably. The implementation of such innovative lighthouse projects at old mine sites is often a milestone for mining communities on their long road to a brighter future. In order to improve abilities and skills, the existing network of companies, universities, government institutions, mining authorities and research centres can be used. Its members can promote a transfer of both knowledge and technologies.

To competently develop post-mining technologies and management skills, many experts and executives need to be qualified in this field. That is why the THGA offers a unique master program in "Geotechnical engineering and Post-Mining" to qualified specialists who will be able to deal with these challenges (16).

This Master Program is the only educational program explicitly dedicated to these issues worldwide. It combines scientific and technical qualifications. The goal, as well as the guiding principle, is to train engineers at the interface of mining, mine surveying and geotechnical engineering, who can plan, execute and direct the complex processes of mine closure, rehabilitation and aftercare in a responsible position.

It aims to educate post-mining experts within four semesters by combining the afore-mentioned topics. To combine practical experience with the theory the program is focusing on part-time students who attend the lectures in the evening while working in a company during the day.

The future post-mining experts need knowledge and skills in geology, hydrogeology, hydrochemistry, rock mechanics and geotechnology, mining, mine site rehabilitation, socio-economic issues, law, business administration, management skills, monitoring techniques and digitalization but also know-how in understanding mine maps, and subsidence etc. Graduates need the ability to define, structure, plan, and process complex projects in geotechnical engineering and post-mining. In doing so, they pay attention to the current global, economic, ecological, and social context. They can recognize challenges and develop solutions independently with the help of engineering methods and modelling tools. Worldwide, there will be the need to have qualified engineers in sufficient numbers for a structured closure and abandonment of mine sites (17).

\section{Conclusion}

The FZN is a competent partner for all areas of post-mining at an (inter-) national level by bundling and integrating the different expertise, respective competences, and skills. The existing and constantly expanded knowledge is disseminated and made accessible worldwide, as it has relevance for many mining regions. For this purpose, the FZN is already carrying out projects as well as training programs for mining companies and executive abroad. 


\section{Literatura - References}

1. Rudolph, T.; Goerke-Mallet, P.; Melchers, C.; Müterthies, A. (2020, eingereicht): Nachbergbauliches Geomonitoring für die E\&P-Industrie. - 1 S. (DGMK Frühjahrstagung 2020, Celle).

2. Kretschmann, J. 2015: The Sustainable Development Strategy of the German Hard Coal Mining Industry. In: Proceedings of 7th Sustainable Development in the Minerals Industry Conference UBC (SDIMI). 7th Sustainable Development in the Minerals Industry Conference UBC. Vancouver, Canada, pp. 1-9.

3. Garcia-Millan, V.; Müterthies, A.; Pakzad, K.; Teuwsen, S.; Benecke, N.; Zimmermann, C.; Kateloe, H.; Preuße, A.; Helle, K.; Knoth, C. (2014): GMES4Mining: GMES-based Geoservices for Mining to Support Prospection and Exploration and the Integrated Monitoring for Environmental Protection and Operational Security. In: BHM Bergund Hüttenmännische Monatshefte 02/2014; 159 (2), S. 66-73.

4. Berg, B. v.; Schmachtenberger, F.; Gruchalla, B. v.; Wollnik, F.; Klaß, S.; Koschare, A.; Schnell, S.; Schliebs, J. (2019): Mineberry - remote monitoring of abandoned shaft openings. In: Proceedings of the 39th International Symposium „Application of Computers and Operations Research in the Mineral Industry (APCOM 2019)“, June 4-6, 2019, Wroclaw, Poland, S. 578-585, 9 Abb.

5. Goerke-Mallet, P.; Melchers, C.; Müterthies, A. (2016): Innovative monitoring measures in the phase of post-mining. In: Drebenstedt, C.; Paul, M. (Eds.): Mining meets water - conflicts and solutions. Proceedings. IMWA 2016 in Leipzig, Germany, July 11-15, 2016. 2., überarbeitete und ergänzte Auflage. Freiberg: TU Bergakademie Freiberg, Institute of Mining and Special Civil Engineering, S. 570-577 (DVD-ROM).

6. Kretschmann, J.; Brüggerhoff, S. (2016): Mining Heritage: Future-orientated Development of an Outstanding Value in Germany. In: Done for Good - Challenges of Post-Mining. Anthology by the Research Institute of Post-Mining. TH Georg Agricola University. Bochum. Eds. Kretschmann, J. and Melchers, C. (Veröffentlichungen aus dem Deutschen Bergbau-Museum Bochum, 2016), pp. 54-55.

7. Route Industriekultur 2020. http://www.route-industriekultur.ruhr/ [accessed 4 February 2020], in German.

8. Rampton, J.; McAteer, N.; Mozuraityte, N.; Levai, M.; Akcali, S. (2011): Ex-Post Evaluation of 2010 European Capitals of Culture. Final report for the European Commission Directorate General for Education and Culture. https:// ec.europa.eu/programmes/creative-europe/sites/creative-europe/files/files/capitals-culture-2010-report_en.pdf [accessed 4 February 2020].

9. European Commission 2017: 2017 EGCA shortlist, retrieved from ec.europa.eu on http://ec.europa.eu/environment/europeangreencapital/applying-for-the-award/2017-egca-applicant-cities/ [accessed 7 February 2020].

10. Kretschmann, J. (2014): Sustainable land management in urban areas. The Ruhr Area as a role model. In: Вестник Кузбасского государственного технического университета, 1, 2014, pp. 127 -132.

11. Magel, H. (2012): Sustainable land management - new challenge for surveyors and land experts. Keynote speech at the Conference Land management days in Turkey, 15.-17.11.2012 in Istanbul. http://www.landentwicklung-muenchen.de/master/news/Istanbul/Magel_LM_Istanbul.pdf.

12. World Bank, (2006): Sustainable Land Management. Challenges, Opportunities, and Trade-offs. Washington D.C.: World Bank Publications.

13. Töpfer, K.(2011): Climate Governance. In: Volkswagen Stiftung/Stiftung Mercator (ed.): Our Common Future, conference summary report. Hamburg: G+J Corporate Editors, 2011, 108-109.

14. Kretschmann, J.; Hegemann, M. (2012): New chances from old shafts. Risk management in abandoned mine sites in Germany. In: Proceedings of the Annual Meeting of the Society for Mining, Metallurgy \& Exploration, Seattle, Washington, USA. Red Hook, NY: Curran Associates, pp. 153-158.

15. Steinkohle 2016: Kreativer Wandel (Creative Change). Steinkohle, 10/2016, S. 7-9, [in German].

16. TH Georg Agricola (2019): Master Program: Geotechnical Engineering and Post-mining. https://www.thga.de/wissenschaftsbereiche/georessourcen-und-verfahrenstechnik/master-studium/geoingenieurwesen-und-nachbergbau/ [accessed December 15, 2019].

17. Melchers, C.; Goerke-Mallet, P. (2016): Research Institute of Post-Mining. TH Georg Agricola University, Bochum/ Germany - Strategies, Activities and Research Priorities. In: Done for Good - Challenges of Post-Mining. Anthology by the Research Institute of Post-Mining. TH Georg Agricola University. Bochum, Eds. Kretschmann, J. and Melchers, C. (Veröffentlichungen aus dem Deutschen Bergbau-Museum Bochum, 212), pp. 11-18, in German.

18. Research Institute for Post-Mining at the TH Georg Agricola University. www.fzn.thga.de [accessed October 30, 2019]. 
Obszary badawcze nad terenami pogórniczymi - Doświadczenia z niemieckiego górnictwa węgla kamiennego

Niemiecki przemysł węgla kamiennego zamkną ostatnia czynna kopalnię pod koniec 2018 roku. Instytut Badawczy ds. terenów pogórniczych (FZN) Uniwersytetu TH Georg Agricola (THGA) w Bochum/Niemcy opracował zintegrowane podejście, aby sprostać wyzwaniom epoki pogórniczej. Dlatego zagadnienia związane z terenami pogórniczymi obejmują cztery obszary badawcze: ciagła i nieustanna gospodarka wodami kopalnianymi; Geomonitoring na terenach pogórniczych; Nauka o materiałach dla zachowania dziedzictwa przemysłowego; Reaktywacja i przejście.

Instytut stara się spetnić główne wymagania ONZ dotycząceodpowiedzialnego i zrównoważonego obchodzenia sięz zasobami naszej planety. Planuje być częścią krajowej i międzynarodowej sieci winteresie wszystkich grup społecznych i środowiska.

Słowa kluczowe: tereny pogórnicze, dziedzictwo przemysłowe, zrównoważony rozwój, przemysł weglowy 